| ISSN:0120-8454 | No.70 | Año 1 | pp. 219-243 |

\title{
Señor que no conoce la luna: la apuesta escéptica de Evelio Rosero Diago*
}

\author{
Juana Alejandra López Lozano** \\ Alexander León López Causado***
}

\section{Resumen}

En Señor que no conoce la luna, el escritor colombiano Evelio Rosero Diago configura dos mundos enfrentados en una relación de poder: los dominantes (sociedad vestida) y los dominados (comunidad desnuda). El héroe -un desnudo lúcido- ante la degradación del mundo en el que habita decide refugiarse dentro de un armario. Desde este espacio asume una actitud de escepticismo frente a la realidad circundante: un mundo moderno en el que se percibe el fracaso del Proyecto Ilustrado, siendo imposible la construcción de un individuo autónomo, libre y feliz. En un intento por dilucidar la toma de posición asumida por Rosero Diago en Señor que no conoce la luna, en el presente artículo se efectúa el análisis de los niveles de producción de sentido presentes en la novela. Para ello, se recurrirá a la noción de toma de posición y de puesta en forma, conceptos fundamentales dentro de la propuesta sociológica de Pierre Bourdieu, relacionada con la génesis de la obra literaria.

* Resultado de investigación realizada en el Seminario Andrés Bello, Instituto Caro y Cuervo.

** Licenciada en Lingüística y Literatura. Universidad Distrital Francisco José de Caldas. Candidata a Magíster en Literatura Hispanoamericana. Instituto Caro y Cuervo. E-mail: phoennix54@gmail.com.

*** Profesional en Lingüística y Literatura. Universidad de Cartagena. Candidato a Magíster en Literatura Hispanoamericana. Instituto Caro y Cuervo. E-mail: pezneutro74@yahoo.es. 


\section{Palabras clave}

Escepticismo, toma de posición, puesta en forma, escritura lírica, Evelio Rosero Diago.

\section{Abstract}

In Señor que no conoce la luna, Colombian writer Evelio Rosero Diago set up two confronted worlds in a relationship of power: dominators (dressed society) and dominated (naked community). The hero-a lucid naked-faced with degradation of the world where he lives, decides to take shelter inside a wardrobe. From this space, he assumes an attitude of skepticism opposite to the surrounding reality: a modern world where the Illustrated Project's failure is noticed, being impossible the construction of a happy, free and autonomous individual. In an attempt to elucidate the axiological attitude assumed by Rosero Diago in Señor que no conoce la luna, in the present article an analysis of the meaning production present in the novel is carry out. For that, the notion of the axiological attitude assumed and the literary materialization of this, fundamental concepts inside the Pierre Bourdieu's sociological proposal, related with the genesis of the novel.

\section{Key words}

Scepticism, assumption of position, shape-giving, Evelio Rosero Diago.

\section{Introducción}

La obra literaria es un sitio semiológico en el que se interpreta el mundo y la condición humana desde una posición axiológica particular. Los acontecimientos que se producen en la sociedad generan consecuencias en las categorías mentales de sus integrantes, categorías que se registran en la obra. Así, para efectuar el análisis de la misma y comprender su especificidad, es 
necesario tener en cuenta la estrecha relación que existe entre la novela y el medio socio-cultural en el que ésta se origina.

Con el propósito de dilucidar la toma de posición asumida por Evelio Rosero Diago en la novela Señor que no conoce la luna (1992), se analiza -desde los distintos niveles de producción de sentido- la puesta en forma de la obra. Para tal fin, se recurre a las nociones de toma de posición y puesta en forma, conceptos fundamentales en la propuesta sociológica de Pierre Bourdieu, los cuales no sólo permiten determinar la apuesta que hace el escritor dentro del campo literario, sino también, abordar el hecho literario (como hecho social) en su complejidad.

En Señor que no conoce la luna, Rosero Diago construye un mundo ficcional en el que predominan elementos que se alejan del principio de verosimilitud; en ese sentido, crea personajes hermafroditas que viven desnudos y hacinados en una casa, donde uno de ellos (el héroe) habita dentro de un armario. El desnudo del armario es el encargado de narrar lo que sucede a sus congéneres, quienes se encuentran a merced de la sociedad de los vestidos; lo anterior, permite a Rosero Diago expresar -a través de los ojos del héroeuna actitud de desconfianza frente al desarrollo de un proyecto moderno que imposibilita la construcción de un individuo autónomo, libre y feliz.

Esta hipótesis de interpretación -como particularidad de la toma de posición de Rosero Diago- se convierte, entonces, en el punto de partida que orientará el análisis de la puesta en forma; análisis centrado en los niveles de producción de sentido que privilegia la novela: los paratextos, el cronotopo, el sistema de personajes y el tipo de escritura empleado.

\section{Análisis de la puesta en forma}

Desde el análisis de los paratextos (título, subtítulo e ilustración de la portada) se percibe el contenido esencial de la novela. Al analizar el título, en primera instancia, es significativa la ausencia del artículo determinativo «el», forma gramatical que suele acompañar sustantivos masculinos en singular. Esta omisión actúa como indicio de una problemática esencial registrada 
en la obra: la imposibilidad de la construcción del individuo; así, «Señor», a diferencia de «el señor», niega la posibilidad de concreción del individuo. Dicha condición se hará extensiva al predicado de la oración («no conoce la luna»), puesto que en éste, el adverbio de negación insiste en la imposibilidad -a la que se enfrenta un individuo que no lo es, (no logra constituirse como tal)- de alcanzar un estado ideal. En este sentido, la luna -como símbolo romántico- representa la utopía, el sueño, y se opone a la realidad degradada y hostil que impide al individuo emerger.

Esta doble negación -imposibilidad de construcción del individuo y, por lo tanto, imposibilidad de construcción de la modernidad, tal como prometía el Ideal Moderno- se reafirma en el subtítulo: «El delirio de un extraño personaje frente al mundo moderno». El subtítulo, en esta oportunidad, adquiere relevancia no sólo porque permite ampliar el análisis del sentido que subyace en el título del texto, sino también, por el carácter poco común del subtítulo en obras literarias (es poco frecuente su aparición). A partir del subtítulo de esta novela se puede esclarecer que la imposibilidad de construcción del individuo -enunciada en el título- es una problemática que surge en relación con un mundo moderno, cuyo desarrollo dista de lo planteado por el Ideal Moderno. Así, el hombre aparece como un ser extraño frente a un mundo en el que los ideales del Proyecto llustrado han fracasado.

El contenido esencial de la obra, actualizado en los paratextos, se amplía en los distintos niveles de sentido presentes en la misma. Es así como, en Señor que no conoce la luna, Rosero Diago construye un universo ficcional en el que el héroe (un desnudo lúcido caracterizado, entre otras cosas, por el brillo en sus ojos, uñas largas y afiladas, extrema delgadez e inusual estatura), como ya se mencionó, ocupa de manera permanente un armario, ya que la casa donde vive es pequeña para la cantidad de desnudos que la habitan. Desde este espacio de soledad y oscuridad percibe el mundo externo, tanto el de los vestidos como el de los desnudos. A partir de este contraste emerge un elemento esencial en la configuración axiológica de la obra: la oposición vestidos/desnudos; oposición en la que, a su vez, reside la disensión dominante/dominado como antagonismo que subyace al ejercicio del poder. 
Las prendas de vestir simbolizan poder: el poder que detenta la sociedad vestida respecto a la vida de los desnudos, materializado en el control que ejercen sobre los alimentos (cantidad de víveres con que abastecen las cocinas de la casa), el espacio (se restringe la movilidad de los desnudos al área de la casa), la forma, el lugar y el momento de la muerte de cada desnudo. De esta manera, para los vestidos, los trajes se convierten en un indicador que les permite establecer su posición de dominio frente a los desnudos, puesto que si desean mantener el poder que ejercen sobre los habitantes de la casa deben evitar "sentirse y contemplarse semejantes a [ellos]" (Rosero Diago, 1992, 41) Asimismo, la vestimenta actúa como una coraza bajo la cual se oculta la vulnerabilidad humana; esa vulnerabilidad que comparten tanto desnudos como vestidos. Por eso, los vestidos, dispuestos a encubrir aquello que les hace "igualmente vulnerables" (Rosero Diago, 1992, 13) a los desnudos y que desvirtúa la posición de dominio que ostentan, se aferran a sus prendas, resistiéndose a despojarse por completo de los ropajes que les enviste de poder.

Por su parte, la desnudez de los habitantes de la casa (tal como ocurre a los seres creados por los dioses quienes, según el mito enunciado por Platón en el Protágoras, reciben cualidades y virtudes, pero permanecen desnudos) representa el estado de indefensión en el que se encuentran los desnudos, ante la situación de dominio a la que son sometidos. Sin embargo, respecto al héroe, esta desnudez adquiere un carácter oximorónico: simboliza tanto la esencia y condición de lo humano (en su desnudez se descubre la morada de su yo interior), como el estado máximo de fragilidad y vulnerabilidad a la que es reducido un ser condenado a permanecer en un armario y, por lo tanto, despojado de la posibilidad de construirse como un individuo autónomo, libre y feliz.

Esta oposición vestidos/desnudos da lugar a un nuevo contraste: la calle y la casa como ámbitos en los que se mueven los personajes, y en los cuales se condensan relaciones espacio-temporales permeadas por axiologías específicas. En la calle, cronotopo de los vestidos, la vida se encuentra organizada de tal manera que estos puedan mantener encerrados a los desnudos dentro de la casa y, así, perpetuar el dominio que sobre ellos ejercen; pese a esto, con 
frecuencia, propician la salida ocasional de algún desnudo con el propósito de obligarle a cumplir oficios poco decorosos (lavar letrinas, asear establos, deshollinar chimeneas, servir de bastón, de juguete, de espantapájaros), o con la intención de probar novedosos artefactos de tortura, y criaturas diseñadas o adiestradas para delatar y exterminar al desnudo que ose exhibir en la calle "la desgracia de sus dos sexos sin sosiego" (Rosero Diago, 1992, 16)

Esta actitud obedece a la lucha de la sociedad vestida por mantener el orden, puesto que la exposición de los desnudos -de su hermafroditismo- en el ámbito público (calle), se constituye en una amenaza: es «lo otro del orden», aquello que al contener el "hedor de lo indeterminado y lo impredecible" (Bauman, 1996, 81) cuestiona el orden que ha establecido quien tiene el poder. Así, los trasgresores son marginados (reducidos al espacio de la casa) y castigados (condenados a tortura, represión y muerte arbitraria), porque aunque desconozcan -a excepción del héroe- el poder que les confiere el «desorden» de sus dos sexos, en estos reside un peligro latente para la conservación del poder que han ejercido los vestidos sobre la comunidad desnuda; es por eso que "la desnudez de nuestro doble sexo los oprime, los deprime, los aflige, los irrita hasta otra clase de dolor: el odio" (Rosero Diago, 1992, 13).

En la sociedad vestida, el odio hacia los desnudos adquiere la forma de tabú: "nadie quiere ver desnudos en la calle, y mucho menos en su casa" (Rosero Diago, 1992, 11); prohibición irracional sustentada en la necesidad de conservar el orden impuesto. El tabú suscitado respecto a la desnudez y, por lo tanto, a la visibilidad del hermafroditismo de los habitantes de la casa en la calle, provoca reacciones violentas por parte de una sociedad que condena -al encierro y la tortura- a quien desafía el orden dispuesto por el poder.

Un orden basado en una lógica que no admite la diferencia y busca regular los comportamientos de las personas promoviendo ciertas costumbres. Es así como, desde niños, los vestidos han aprendido que es impropio exhibir su cuerpo desnudo tanto en espacios privados como en lugares públicos, de manera que suelen andar "permanentemente vestidos, incluso cuando duermen" (Rosero Diago, 1992, 12), repudiando la conducta de quienes traspasan el límite de lo permitido. 
Por esta razón, si ven un desnudo en la calle, los vestidos muestran gestos de incomodidad y nerviosismo; "sufren pataletas, enrojecen, enverdecen y jadean" (Rosero Diago, 1992, 17) de sólo pensar que los desnudos puedan pasearse tan tranquilos por las calles, por los mismos sitios donde están sus hijos y sus mujeres, exhibiendo dos sexos en un solo cuerpo, ese caos que desafía la división social entre lo masculino y lo femenino. Es así como, en nombre del orden y de su «superioridad», los vestidos vigilan, controlan y subyugan a los habitantes de la casa, encadenándolos indefinidamente a los muros de la misma pues, como bien lo saben, "la calle no corresponde a los desnudos" (Rosero Diago, 1992, 17).

Precisamente, en esta afirmación reside el espíritu de una sociedad que privilegia una sola "forma verdadera de realizar la humanidad"(Vattimo, 1990, 84) una lógica unitaria que excluye toda individualidad ajena a sus parámetros. Pese a esto, la sociedad vestida se empeña en mantener en pie la casa de los desnudos: "sostienen permanentemente su armazón, desde afuera [...], luchan contra el desmembramiento" (Rosero Diago, 1992, 45), enderezan techos y refuerzan la puerta, pues saben que su existencia es necesaria para perpetuar el dominio, para propiciar el avance científico y tecnológico (crear artefactos cada vez más sofisticados de tortura y de guerra) y para justificar su «superioridad».

Al aceptar la existencia de un centro que les permite organizar los acontecimientos desde un solo punto de vista, los vestidos admiten también que la historia es algo unitario. Este ideal de Historia y, por lo tanto, de Progreso presente en la mentalidad de los vestidos -vinculado con un "plan racional de mejoras, educación [y] emancipación"- (Vattimo, 1990, 76) permite visualizar la calle como un espacio regido por la linealidad del tiempo. Cuando un desnudo sale a la calle, comienza a sentir los rigores del tiempo que avanza; desde que debe "abrir la puerta cautelosamente y aparecer de improviso, sobresaltado, y dar un primer paso -desalentado-y otro lívido y otro erizado y otro casi-casi desmayado y enfrentar en vilo la congoja de una calle ajena" (Rosero Diago, 1992, 53). 
El mundo de los vestidos se rige, entonces, por una total confianza hacia el futuro: «"Algún día”, predicen los científicos en voz baja, "seremos capaces de reducir esta casa. La volveremos una casa de juguete", y arrojan una carcajada general" (Rosero Diago, 1992, 41) Creen en el progreso y en el poder de la ciencia para desarrollar avances científicos y tecnológicos que les haga más fuertes; sin embargo, contrario al perfeccionamiento de la condición humana al que se aspiraba con la noción de Progreso (mejoramiento paulatino de la civilización), la sociedad vestida -ajena a cualquier sentimiento de bondad- ha convertido la calle en un locus terribilis para los desnudos: un lugar degradado y hostil en el que deben soportar torturas y humillaciones, un lugar donde se encuentran al acecho de una muerte violenta.

Interesados en el perfeccionamiento del "difícil arte de atormentar desnudos" (Rosero Diago, 1992,13) los científicos diseñan sistemas de tortura, centinelas, armas y aparatos que garanticen su «superioridad»; así, se pone la Razón al servicio de las «catástrofes del progreso»: la represión, la tortura, la guerra. El perfeccionamiento de artefactos de destrucción se convierte, entonces, en el objetivo primordial de los hombres de ciencia; propósito que les lleva a desafiar las leyes de la naturaleza -crean seres monstruosos producto de "perseverantes vivisecciones, entre ellos una tortuga-liebre, un caballo alado, una vaca-rana, un gato-pájaro, una gallina con dientes"- (Rosero Diago, 1992, 24) y pervertir la razón humanista exaltada por el Ideal Moderno.

Los vestidos hacen parte esencial de una sociedad en la que, desde la mirada crítica del desnudo del armario, se hace evidente el fracaso del Ideal Moderno. Pese a las ideas de Razón y Progreso, y a la exaltación de valores tan altos como la igualdad, la libertad y la fraternidad, en la práctica, el perfeccionamiento de la condición humana y la razón lúcida son cuestionadas. Una sociedad que confía ciegamente en la Razón Instrumental no se consolida como un espacio propicio para construir un individuo autónomo, libre y feliz; los vestidos "no son felices, aunque muchos de ellos estén vestidos de payasos y ostenten una gorda risotada pintada en los labios. Pero nosotros tampoco somos felices" (Rosero Diago, 1992, 24-25) 
La ausencia de felicidad en los desnudos obedece, entre otras cosas, a que se encuentran reducidos al espacio de la casa, segundo cronotopo esencial en la novela. Simbólicamente, la casa suele identificarse con ese pequeño universo primigenio que brinda estabilidad y protección al ser humano (vientre materno); no obstante, la casa de los desnudos se constituye en una prisión para sus habitantes: un lugar de muros húmedos y desgastados, donde la ausencia de luz natural y de ventilación, alterna con el hacinamiento y el hambre incesante. Así como la casa "fue también una cárcel para su primera habitante" (Rosero Diago, 1992,45) los desnudos están condenados a permanecer tras sus muros hasta cuando los vestidos decidan lo contrario.

En la casa, multitud de cuerpos "deambulan amarillos y desnudos, húmedos y apretados, por los patios de cemento y las tortuosas galerías" (Rosero Diago, $1992,10)$ ensimismados en la búsqueda de algo que pueda aliviar un poco la pesada carga que supone un estómago vacío. Estos cuerpos amarillos -cuya coloración evoca su cercanía a la muerte- van a identificarse también con el color blanco (ambos colores conservan una profunda afinidad por su tendencia a la claridad). El blanco -tono que predomina en el héroe- será símbolo "de totalidad y la síntesis de lo distinto"; (Cirlot, 1969, 110) en este sentido, la blancura de los desnudos se relaciona con su carácter andrógino: seres completos, en los que se alcanza la síntesis de contrarios.

Pese a que los desnudos se constituyen en seres más completos, la escasez de comida y el hacinamiento al que han sido sometidos -por parte de los vestidos- propicia el surgimiento de conductas que limitan la existencia de los habitantes de la casa a la satisfacción de necesidades momentáneas: el hambre, el sueño o el deseo libidinal. A diferencia del héroe -quien ya se ha acostumbrado a la ausencia de alimento- los desnudos dedican la mayor parte del tiempo a pensar en cómo saciar un hambre pródiga y eterna. El control sobre los alimentos se constituirá, entonces, en uno de los mecanismos utilizados por los vestidos para perpetuar su poder frente a los desnudos.

Los cocineros -desnudos que encabezan el grupo de favoritos- representan, a través de la preparación y repartición de los alimentos, el orden que los 
vestidos desean imponer en la casa. Por esta razón, estar con un cocinero "es como estar con cualquiera de los vestidos" (Rosero Diago, 1992, 64) ya que -además de comer bien y tener acceso al manejo de los cuchillos- son los encargados de escoger el desnudo que debe salir para abastecer de víveres las alacenas, establecen quien tiene la razón cuando se presentan enfrentamientos, controlan que ningún desnudo tenga las uñas largas y se encargan de sepultar tanto a los desnudos que mueren por tortura, como a los muertos subrepticios; es decir, los desnudos que finalizan despedazados y desaparecidos dentro de la casa, sin la presencia de testigos directos y sin que nadie vuelva a saber de ellos.

El grupo de los favoritos también está conformado por otros desnudos que gracias a su talento, atractivo o fortaleza reciben la protección de los vestidos: tienen siempre disponible un plato de comida, gozan de un nombre invariable que los distingue de los demás y no corren el riesgo de ser escogidos para salir a enfrentar en la calle "la humillante solicitud de víveres" (Rosero Diago, 1992, 53) Pese a las ventajas de las que gozan los favoritos, al igual que los demás desnudos, están condenados a cumplir con el papel de marionetas, cuerpos que se usan y desusan según los deseos de la sociedad vestida. Porque en eso se les va la vida a los desnudos, en que les usen "para cualquier menester, de platos, de candelabros, de vasijas, de mesas para sus comidas" (Rosero Diago, 1992, 25) de nodrizas, de bufones que les distraen del aburrimiento, les proporcionan caricias voluptuosas y les hacen reír.

Es así como ni siquiera durante las fiestas organizadas en la casa, esta acumulación de cuerpos desnudos -pero completamente solos e inermes- puede disfrutar de la emoción colectiva que proporciona el momento orgiástico. Sus cuerpos desnudos y anónimos están allí para cumplir las pretensiones de los visitantes quienes, a pesar de que "parecen amables cuando están dentro de la casa" (Rosero Diago, 1992, 39) mantienen en este espacio las relaciones de dominación establecidas en la calle, disponiendo de los desnudos a su gusto.

Por eso en las fiestas, aunque los vestidos "se divierten con gran intensidad" (Rosero Diago, 1992, 39) no permiten que las diferencias que se han establecido entre ellos y los habitantes de la casa sean quebrantadas. Por 
tal razón, nunca se desnudan por completo, e infringen castigos y torturas mortales cuando se sienten burlados o desobedecidos por algún desnudo. Su poder no tiene límites: tanto en la calle como en la casa buscan conservar el orden, controlar las actuaciones de los desnudos y mantenerlos "siempre insatisfechos con las comidas" (Rosero Diago, 1992, 31) para perpetuar el sometimiento.

Tan desnudos como sus nombres, los habitantes de la casa -en oposición al héroe- no entienden el valor de su desnudez, ni saben quienes son. Esta situación les ha convertido en seres sumisos dominados por el miedo: un inmenso temor frente al poder de los vestidos ha anestesiado su capacidad para interrogarse, para "cavilar en torno a [...su] historia y condición"; (Rosero Diago, 1992, 62) de tal manera, se resignan a la esclavitud, la tortura y la muerte impuesta, sin oponer resistencia, sin revelarse pues, a excepción del desnudo del armario, carecen de la "misteriosa inclinación por defenderse" (Rosero Diago, 1992, 61)

Esta falta de conciencia respecto a su condición, sumada a la permanente represión a la que se encuentran sometidos, anula el poder de decisión de los desnudos frente a sus propios actos. La ausencia de autonomía amenaza su libertad; no sólo están condenados a permanecer encerrados en la casa hasta que lo decidan los vestidos, sino que están obligados a actuar "sin que se desprenda nunca un solo indicio de razonamiento propio, o sueño, o lejanía" (Rosero Diago, 1992, 34) con lo cual se ven despojados de la posibilidad de recurrir a la razón o a la imaginación como formas de alcanzar un proceso de liberación.

Despojados de la posibilidad de plantearse un proyecto de vida que les permita superar el nivel de lo material y lo inmediato, los desnudos viven el aquí y al ahora, lo que les impide cuestionarse -a excepción del héroe- acerca de su condición y su pasado. En la casa, en los objetos y utensilios, es imposible encontrar vestigios de sus primeros habitantes: los rastros de un posible pasado se encuentran fuera de ésta, en el cementerio de los desnudos, "una larga frazada de tierra negra, muy negra, marcada por sauces y peñascos, a las espaldas de la casa" (Rosero Diago, 1992, 44) 
De esta manera, contrario al avance temporal que caracteriza el espacio de la calle, en la casa, sus habitantes no perciben una progresión del tiempo en el espacio; soportan una vida signada por la rutina, por "la costumbre eterna de las mañanas idénticas y las idénticas tardes y las noches idénticas y ellos idénticos en la mitad de una idéntica pared" (Rosero Diago, 1992, 52) Así, los desnudos permanecen en un presente constante, "girando desnudos y con dos sexos [... entre un desnudo tumulto" (Rosero Diago, 1992, 49) Dos sexos que, como se sabe, son objeto de repudio ante los ojos de la sociedad vestida.

El estado bisexuado del que gozan los desnudos -esa posibilidad de integrar una humanidad común, en un solo cuerpo- desafía las distinciones sociales que impone el «sexo morfológico» (hombre o mujer) y privilegia las del «sexo psicológico» (sentirse más hombre o más mujer). Esta posibilidad de pasar de un sexo al otro otorga a los desnudos la libertad para "disponer de [... su] propia identidad sexual" (Lipovetsky, 2000, 93) así, la decisión frente a sus dos sexos -ser desnudo o desnuda- se constituye en el único aspecto en que los habitantes de la casa ejercen su libertad, puesto que en esta elección sólo interviene la sensibilidad personal de cada desnudo. Por eso, en la casa es frecuente encontrar adolescentes "que no se han decidido todavía por ser más hombres que mujeres, o al revés, peinándose tristemente frente al espejo" (Rosero Diago, 1992, 73-74) en espera de alcanzar una pronta y satisfactoria resolución.

La relevancia que los desnudos otorgan al templo del yo, sumada al desconocimiento de sus antepasados más cercanos (padre, madre), son conductas impuestas por la sociedad vestida que debilitan cualquier intento por establecer lazos filiales. Las desnudas no suelen manifestar instintos maternales frente a sus crías; las más pacientes, les soportan durante sus primeros años de vida y, cuando consideran que ya pueden defenderse, "los sueltan, los echan al tumulto de la desnudez, los olvidan" (Rosero Diago, 1992, 48). El padre, desnudo o vestido, permanece prácticamente ausente desde el momento mismo de la concepción, de manera que, en estas circunstancias, tampoco se reconoce la existencia de hermanos. 
La imposibilidad para reconocer en el otro un congénere, ante el dominio impuesto por los vestidos, convierte a los desnudos en seres que no reconocen la obligación de unirse a algo que no sea uno mismo (Lipovetsky, 2000, 12). Este rasgo individualista les lleva a preocuparse sólo por satisfacer sus intereses personales inmediatos, sin importar lo que pueda suceder con los demás: están dispuestos a entregar a algún desnudo para saciar temporalmente su hambre, mostrando cierta indiferencia frente a la muerte del acusado.

Los límites de la casa y los de la calle se encuentran demarcados por el umbral de la puerta. Espacio asociado con el motivo del encuentro, al comunicar el mundo de los desnudos con el de los vestidos, el mundo de un presente constante con otro donde la temporalidad es progresiva (lineal). Sin embargo, para los desnudos, el umbral implica el "momento de la ruptura en la vida, de la crisis, de la decisión que modifica la vida" (Bajtin, 1989, 399) puesto que pasar el umbral de la casa es pasar a un nuevo estado, es arrojarse a los horrores de la calle, a las inmisericordes prácticas de tortura ideadas por los vestidos y quizá, a la muerte. Esto bien lo entiende el héroe y por eso prefiere permanecer en su armario, constituyéndose éste en el tercer cronotopo importante de la novela.

Es así como el armario se convierte en refugio del héroe; un desnudo cuya lucidez le permite entender que los valores presentes en el mundo externo han degradado a sus habitantes, que la Razón Instrumental ha terminado por convertir a los vestidos en seres homogéneos e incapaces de aceptar una realidad que no sea compatible con sus parámetros. En otras palabras, el dogmatismo reinante en ese mundo hace que cada una de sus normas y convenciones sociales se tornen en verdades absolutas e incuestionables; situación que genera cierta inadecuación del héroe con la sociedad vestida.

Desde el inicio de la novela se señala la clase de ruptura que tiene el héroe con el mundo, puesto que refugiarse en el armario implica un rechazo vertical con la realidad: "Es cierto que esta casa es inmensa, pero nosotros somos demasiados. Pues para que todos quepan dentro de la casa, hace falta que haya uno, por lo menos, metido dentro del armario. Y soy yo, generalmente 
quien vive dentro del armario" (Rosero Diago, 1992, 9). El "soy yo" pone en evidencia que el héroe se asume como responsable de su actitud, pero a la vez es una marca que caracteriza el tipo de narración: en primera persona y en tiempo presente. Ahora bien, cuando afirma que "nosotros somos demasiados" se incluye dentro de una comunidad que, aunque en los primeros párrafos no se aclara de qué tipo es, posteriormente se pondrá de manifiesto que es un tipo de comunidad que se aparta, literal y simbólicamente, de las sociedades donde predomina el uso de prendas de vestir.

Pese a constituirse en un espacio de calma y tranquilidad en el que el héroe se aísla, el armario resulta "una vivienda relativamente incómoda" (Rosero Diago, 1992, 9); de este modo, se percibe una de las primeras ambivalencias por las que atraviesa el héroe a lo largo de la novela. Dentro del armario, en contraposición al mundo de los vestidos, el tiempo está a favor del héroe, puesto que al detenerse lo aísla de los conflictos del mundo externo y, a la vez, le acerca a una relativa plenitud de su ser, que si no fuese por los problemas sociales que percibe sería completa. Además de lo anterior, este espacio le permite al desnudo del armario distanciarse de la vida cotidiana de la casa, cuya actividad está regida por un presente constante.

En el armario, el héroe ha construido un agujero que le permite observar la dinámica dentro de la casa; orificio realizado de forma rudimentaria, de modo discreto y con la paciencia de los años: "mis uñas han logrado hacer con el tiempo un pequeño agujero a modo de ventana" (Rosero Diago, 1992, 9) asegura el héroe, señalando con esto el modo elemental de trabajo, en contraste con los avances científicos y tecnológicos que posee la sociedad vestida.

Lo anterior, indica la marginalización y el atraso de la comunidad desnuda; pero, además, señala una forma de sometimiento por parte de una sociedad opresora, que no les permiten obrar libremente. La presencia de un agujero en el armario no sólo revela el comportamiento vigilante que asume el héroe ante los vestidos y los propios desnudos, ya que siente desconfianza respecto a lo que está fuera de su morada, sino también, indica la imposibilidad de ver la realidad como una situación impuesta por los vestidos. Pese a esta 
restricción, la lucidez del héroe le lleva a refugiarse en el armario y, desde allí -a través de su ventana- observar sin ser visto.

En sentido general, la ventana representa el símbolo de la luz o de la claridad que penetra en la casa, iluminando todo lo que en ella se encuentra; por medio de la ventana, la casa se abre al mundo y todos sus habitantes entablan una relación con el exterior, bien sea para aceptarlo o rechazarlo. La casa de los desnudos no tiene esa posibilidad porque, aparte de la puerta de entrada, todas las aberturas han sido selladas; sin embargo, la ventana que ha construido el héroe funciona como el ojo de su vivienda, que si bien no le permite mirar - de manera directa- la realidad que está más allá del umbral de la casa, si le posibilita observar lo que proviene de ese mundo, construyendo así juicios sobre el exterior.

De este modo, con su retiro, el desnudo del armario muestra apatía hacia los valores que rigen la sociedad vestida; valores que se erigen como verdades absolutas e incuestionables. Su aislamiento conlleva un grado de sospecha hacia el proyecto de la sociedad vestida, en la cual sólo se piensa en utilizar la razón con fines bélicos: "Ios oficiales, los hombres de ciencia, los de leyes, los de letras y los prácticos hablan solamente de la guerra, [...] sueñan con la guerra, se duermen con ella, se despiertan abrazados a ella" (Rosero Diago, $1992,40)$

Es inevitable observar la tensión entre el mundo de los vestidos y el mundo del héroe, cuya interioridad constituye una suerte de «cosmos interno», autónomo y autosuficiente; cosmos interno que "no es un hecho meramente anímico, sino un decisivo juicio de valor acerca de la realidad" (Lukács, 1985. 381) Ante esa oposición, el desnudo del armario se presenta como un héroe problemático cuya subjetividad no puede ser exteriorizada en la sociedad vestida, porque hay unas medidas represivas contra él y su comunidad, pero también, porque su alma se manifiesta más «ancha» que la realidad en la que vive.

Esta inadecuación radical, sumada al estado de sometimiento e impotencia en el que se encuentra, marca la tendencia del héroe hacia la pasividad:"ten- 
dencia más a evitar conflictos y luchas externas que a asumirlos, tendencia a resolver exclusivamente dentro del alma todo lo que al alma afecte" (Lukács, $1985,380)$ No obstante, a diferencia del héroe romántico de la desilusión, propuesto por Lukács, la ruptura con el mundo que ha provocado el desnudo del armario es más radical, en tanto que los conflictos que percibe no tienen solución; no se resuelven luchando porque es imposible la lucha en un estado de indefensión, no los resuelve -exclusivamente- dentro de su alma porque residen tanto en ésta como en el mundo; así, su tendencia a la pasividad es más una imposición que algo que él haya buscado. Pasividad que concede al héroe un matiz propio del escepticismo, al buscar en su armario la imperturbabilidad y la calma que caracteriza la ataraxia de los escépticos.

En ese sentido, el desnudo del armario es un yo aislado de los demás. Vive su propia realidad lejos de los otros desnudos, llegando incluso a odiarlos, "Hoy me parece que debo sentir más odio por los desnudos de la casa que por los vestidos que los torturan"; (Rosero Diago, 1992, 73) con ello, demuestra que si bien pertenece a una comunidad, en él perviven intentos por autoconstruirse como individuo, partiendo siempre de su diferencia con los otros. Aquí, surge una nueva ambivalencia en el héroe: mientras al principio de la novela se reconoce como participe de una comunidad, a medida que ésta transcurre aflora en él un desprendimiento de esa sociedad, lo cual consigue al final de la novela con su muerte.

A través de sus comentarios, el héroe reflexiona acerca de lo que percibe a su alrededor; reflexiones en las que muestra con lucidez su toma de conciencia ante mundo. Así, revela un vasto horizonte de conocimiento donde no hay cabida para la estrechez de la mente, aspecto que lo vinculará a los presupuestos del escepticismo de Pirrón en la antigüedad, y de Montaigne en la época moderna, grandes pensadores que describieron su manera de ver el mundo en periodos de transición. El héroe de la novela también describirá el mundo (nunca teoriza sobre él) a través de su percepción: “A veces optan por ponernos a hacer oficios, humillándonos. Lavar y cepillar sus letrinas. Desinfectar sus colchones. Asear y ordenar sus establos. Brillar hasta la luz el pelo de sus marranos. Deshollinar las chimeneas. Dormir con sus paralíticas nonagenarias" (Rosero Diago, 1992, 25) 
En esta actitud descriptiva se puede leer el distanciamiento que asume el héroe con la realidad del mundo externo, siendo ésta la mejor manera de cuestionarlo; también puede interpretarse como una negativa a comprometerse con verdades absolutas, las cuales propondrían salidas a las distintas problemáticas del mundo y le llevaría a adoptar una postura esperanzadora, de la que se encuentra bastante alejado. De ese modo, el héroe se asume y se reconoce como un individuo diferente: tiene la certeza de su fracaso frente al mundo y de su vulnerabilidad ante una sociedad que corroe los valores del individuo; una sociedad vestida que no se rige por un deber-ser imperativo orientado hacia el bienestar de sí mismo y de los demás, sino donde "el mal se espectaculariza y el ideal está poco magnificado" (Lipovetsky, 2000, 48)

Eso mismo percibe el héroe cuando relata el placer que produce a los vestidos las torturas a las que son sometidos los desnudos, al no considerarlos como sus iguales; torturas convertidas en espectáculos públicos que tienen como propósito el alivio de enfermedades y, en el caso de las mujeres jóvenes, la excitación sexual:

En cuanto a las más jóvenes, las no desposadas, por ejemplo, se sabe que durante las escenas de tortura suelen pasarse y repasarse sus lenguas rojas y vibrátiles por encima de las bocas resecas, los dientes marfilinos muerden la carne brillante de sus labios, todos de pie, [...] se dan compactos y redondos golpecitos en el vientre, pasan y repasan la yema humedecida de sus dedos por encima de los pezones erectos, como para reduplicar en sus cuerpos la sensación de la monstruosa caricia proveniente del dolor de los desnudos. (Rosero Diago, 1992,17)

Lo anterior, pone de manifiesto que el héroe va endureciendo cada vez más su actitud crítica y se va alejando del mundo que lo oprime. Distancia que le lleva a refugiarse en su interioridad, adoptando un lenguaje lírico, expresado a través de un monólogo permanente; sin embargo, este lirismo ni se asemeja al de la época clásica (no tiene en cuenta la musicalidad ni los aspectos formales), ni asume la forma que señala Lukács para el héroe romántico de la desilusión, puesto que su subjetividad lírica se crea a sí misma 
pero "no se contrapone con recusación polémica al mundo externo que le está coordinando" (Lukács, 1985, 381).

Por el contrario, el desnudo del armario se afirma y se reconoce a partir de su desnudez, sin la necesidad de la añoranza por el mundo externo porque, ante todo, hay una ruptura vertical que no permite grados de contemplación; por consiguiente, éste es un lirismo que deviene de una actitud crítica adoptada desde su interioridad. Esa atmósfera lírica se manifiesta -a nivel textual-en el empleo de algunos recursos lingüísticos, en una particular forma de organización de la escritura y en la utilización de un léxico que denota el estado anímico del héroe: "soy un vapor largo y raquítico, hay niebla en mis axilas, mi boca es blanca, soy una espátula de gelatina, desperezo en el dolor, barboto gemidos, soy un rugido, mi cuerpo espumoso tiembla engarrotado, mis ojos sufren enrojecidos por la luz" (Rosero Diago, 1992, 10).

Así, el lirismo empleado en la novela se caracteriza por la presencia de frases cortas y condensadas (semejantes a versos), y por el predominio de descripciones en las que se manifiestan estados anímicos del yo, las cuales denotan sufrimiento: dolor, gemidos, rugido, tiembla engarrotado, sufren enrojecidos; además de esto, hay una cadena de significantes que no está unida por unidades gramaticales, sino por un nexo de carácter semántico, de tal manera que cada frase posee un significado que está relacionado con el de la frase anterior y con la siguiente.

En este sentido, cada frase alcanza su propio valor semántico -como en la poesía lírica- sin depender de las otras, mas en su conjunto contribuyen a formar el significado global del fragmento. Esta escritura lírica se caracteriza también por la ubicación temporal del presente, en cuanto momento permanente y concordante que pretende unir lo que sucedió con lo que vendrá, intensificándose así la emotividad "del sujeto lírico, es decir de la primera persona gramatical, [situada] en un tiempo presente del que toman sentido el pasado como memoria y el futuro como deseo o temor" (Martínez, 1990, 44).

La ubicación de ese yo en un tiempo presente se evidencia en las formas verbales que emplea el héroe-narrador (tiemblan, sufren, grito, suspiros, 
muero, despedazado, aplastado...), las cuales refuerzan su estado emotivo ante un mundo que lo oprime: "este abandono que hoy sentimos por nosotros mismos, esta esclavitud insoslayable en la que hemos permitido que nos hundan"; (Rosero Diago, 1992, 46) esto es lo que siente la voz narradora del héroe en su presente, es decir, una sensación de derrota que está unida a los recuerdos de las torturas y vejámenes a que han sido sometidos algunos desnudos. Por eso, él no puede sentir más que una sensación de temor hacia lo que algún día podrían hacerle los vestidos:

Algún día, predicen los científicos en voz baja, seremos capaces de reducir esta casa. La volveremos una casa de juguete', y arrojan una carcajada general, y nosotros nos preguntamos si es posible que lo logren, es posible, pensamos, y todavía seguimos considerándolo, igual que una cercana pesadilla. (Rosero Diago, 1992, 41)

Sensación de incertidumbre que alimenta aún más su escepticismo, el cual se manifiesta también en la forma como los tres espacios esenciales para el desarrollo de la novela (la calle, la casa, el armario), son percibidos y razonados por la conciencia crítica del héroe.

Desde su óptica subjetiva, el desnudo del armario no reconstruye la continuidad de su vida, o de la vida de los vestidos u otros desnudos; reconstruye solamente fragmentos de las impresiones que ha suscitado en su interior aquello que ha vivido, las evocaciones de aquello que recuerda ha escuchado desde su armario, o visto desde su ventana. De ese modo, el héroe se guía por los sentidos, los cuales le permiten conocer y reflexionar sobre el mundo, siendo estos -según Horkheimer- la base fundamental del estilo escéptico, el cual consiste "en dejarse guiar por la experiencia y por el sentido común sensualista" (Horkheimer, 1982, 146).

Por lo tanto, se pone en juego la manera como el héroe reconstruye la realidad a través de su conciencia; realidad que tiene una sola forma de ser, pues es percibida desde el subjetivismo unipersonal del desnudo del armario. De esta manera, el héroe-narrador no sólo reconstruye lo que ve en el aquí y 
el ahora, sino que refuerza esa reconstrucción mediante los recuerdos del pasado. Es así como la novela empieza in media res y en tiempo presente, desde el cual, el narrador va describiendo -de manera no cronológica- la forma como viven los desnudos, las actividades que realizan y cómo actúa la sociedad vestida cuando está cerca de ellos.

Esta fragmentación explica la forma alienada como el héroe percibe la realidad, la cual se organiza en la novela por medio de párrafos demasiado largos la mayoría de las veces, y muy cortos en algunas ocasiones; esto se justifica en la medida en que el héroe-narrador es, a la vez, productor y receptor de su discurso, obviando la coherencia y moderación ante la falta de un otro como receptor. Las novelas en las que se recurre a este tipo de procedimiento producen

...un sentimiento de irresolubilidad, mostrando frecuentemente algo confuso o velado, algo hostil a la realidad que representan, y no es raro hallar en dichas obras un abandono de la voluntad vital práctica, o una propensión a representar sus formas más burdas; fobia a la cultura, expresada con los medios estilísticos más sutiles que la cultura misma ha creado, a veces un afán destructivo encarnizado y radical. (Auerbach, 1979, 520)

En efecto, el héroe muestra una actitud agreste con el mundo ante la ausencia de esperanza respecto a la realización de una vida plena en él. Ese inconformismo le lleva a adoptar una expresión lírica cuestionadora, frontal y decisiva a la hora de emitir su juicio ante la realidad; de ningún modo es un lirismo con una actitud evasiva, como el de los románticos modernos, sino que se presenta como un lenguaje renovado que hace frente al malestar que se siente en el mundo hoy. Así, el monólogo del héroe es un diálogo interno en el que se efectúa una reflexión cuidadosa de lo percibido, pero sin alcanzar el camino de la certeza. Ante el carácter incierto de la realidad, el desnudo del armario concluye que es imposible conocerla en su totalidad: 
Me pregunto si yo, lejos de este armario, soy distinto.

No lo creo.

O quién sabe.

Quién puede saberlo.

Quién.

Quién (Rosero Diago, 1992, 29).

Al preguntarse, si alejarse del armario implica que él se convierta en alguien distinto, afirma -en primera instancia- "No lo creo", pero después de reflexionarlo un poco se convence que nadie puede saberlo:"Quién puede saberlo. Quién. Quién".

Esa tendencia a evitar las aseveraciones absolutas frente a la realidad se percibe en la utilización de expresiones que generan sensación de irresolución en lo afirmado:"es posible", "quién sabe", "no logro definir", "acaso", "creo que”, "posiblemente", con las cuales manifiesta cierta desconfianza respecto a las verdades absolutas, a la absoluta validez de las opiniones que se expresan frente a lo vivido; "mi razón me señala un camino. Mi otra razón otro camino" (Rosero Diago, 1992, 98) afirma el desnudo del armario consciente de la existencia de múltiples posibilidades para percibir y evaluar la realidad. Todo depende de la manera como, en un momento determinado, se percibe la configuración de las cosas, siendo imposible reducir la realidad a una verdad única y universal.

La única certeza que tiene el héroe la alcanza en los momentos previos a su muerte, al reconocer "que al final únicamente está el abismo"; (Rosero Diago, $1992,98)$ instantes en los que expresa con mayor claridad el carácter lírico de su ser. Es así como, por medio de este carácter, puede apreciarse el desenlace de una vida constituida en sí misma como una obra de arte: el hecho de que sea el mismo desnudo del armario y no los vestidos quienes decidan las condiciones de su muerte, resalta el papel de autor y espectador de su propia existencia. De este modo, el héroe se libera de un mundo opresor y busca la plenitud de su existencia; su muerte, por tanto, se simboliza con el 
color rojo, el cual está ligado fundamentalmente a la vida, a esa plenitud que espera encontrar el héroe con su escape a otro mundo, donde la amplitud de su alma pueda encontrar un lugar. El rojo es un color inherente al héroe y se mezcla con la blancura que le rodea, indicando así su esencia vital.

Su desnudez roja y blanca es símbolo de la esencia de lo humano, valor que contrasta con el mundo degradado de los vestidos; en la desnudez se encuentra la morada de su "yo" interior, lo cual se evidencia en sus reflexiones: "porque sé finalmente quien soy yo, un desnudo, y sé perfectamente que mi nombre está desnudo como yo, y porque en esto soy absolutamente distinto a los demás habitantes de la casa" (Rosero Diago, 1992, 33) De este modo, el carácter oximorónico de la desnudez del héroe muestra, tanto el desamparo en el que se encuentran los habitantes de la casa respecto al poder que ejercen los vestidos, como la tendencia del héroe a mostrar su esencia, al considerar que ya no hay nada que ocultar ante el vacío de la vida.

Lo anterior, contrasta con la sociedad de los vestidos quienes fingen ser felices detrás de sus vestiduras, puesto que éstas no sólo les enviste de poder frente a los desnudos, sino también, les permite ocultar la vulnerabilidad del ser humano; en este sentido, a los ojos del héroe, se presenta una sociedad vestida sumida en las apariencias, y cuya vida se encuentra supeditada al orden que ellos mismos se han impuesto:

a lo mejor los corroe la inmensa envidia que sienten por nuestra desnuda manera de vivir; una envidia sin fundamento, me parece, pues ellos mismos si quisieran, podrían desnudarse y caminar así, desnudos, en sus casas, o en las calles si eso desean, cuando hay un buen tiempo, por ejemplo, y hace sol. (Rosero Diago, 1992, 41)

Así, el héroe no se guía por esa clase de mandatos que impide a los vestidos despojarse de sus ropajes, puesto que su desnudez hace parte de su esencia vital. 


\section{Conclusión}

En suma, el análisis de los niveles de producción de sentido en la novela, permitió dilucidar la toma de posición con dimensiones escépticas asumida por Evelio Rosero Diago en Señor que no conoce la luna. El escritor colombiano mira con desconfianza una sociedad en la que la intransigencia de los dominantes impide la construcción de un individuo autónomo, libre y feliz. Dentro de la novela, esta sociedad se estructura a partir de la conformación de dos grupos: los opresores que ostentan el poder, y los oprimidos que -por su condición desvalida ante el mundo- sufren las consecuencias de éste; antagonismo que impide la consolidación del individuo sólido que promulgaba el Ideal Moderno. Frente a esta situación, Evelio Rosero Diago plantea que el individuo lúcido (desnudo del armario) no tiene más alternativa que escapar de la degradación y hostilidad del mundo recurriendo al refugio interior; actitud que se convertirá, entonces, en una manera de ser en la postmodernidad.

\section{Bibliografía}

Auerbach, E. (1979). Mímesis. La realidad en la literatura. México: Fondo de Cultura Económica.

Bajtin, M. (1989). Teoría y estética de la novela: trabajos de investigación. Madrid: Taurus.

Bauman, Z. (1996). Modernidad y ambivalencia. En J. Berian, Las consecuencias perversas de la modernidad: modernidad, contigencia y riesgo. Barcelona: Anthropos.

Bourdieu, P. (2000). Cuestiones de sociología. Madrid: Istmo.

Bourdieu, P. (1995). Las reglas del arte. Génesis y estructura del campo literario. Barcelona: Anagrama. 
Bourdieu, P., \&Wacquant, L. (1995). Respuestas. Por una antropología reflexiva. México: Grijalbo.

Brun, J. (1977). La desnudez humana. Vitoria: Magisterio Español.

Cirlot, J. (1969). Diccionario de símbolos. Barcelona: Siruela.

Douglas, M. (1973). Pureza y peligro: un análisis de los conceptos de contaminación y tabú. Madrid: Siglo XXI Editores.

Durand, G. (1981). Estructuras antropológicas del pensamiento. Introducción a la arquetipología general. Madrid: Taurus.

Genette, G. (1989). Palimpsestos: la literatura en segundo grado. Madrid:Taurus.

Goldmann, L. (1975). Para una sociología de la novela. Madrid: Ayuso.

Horkheimer, M. (1982). Historia, metafísica y escepticismo. Madrid: Alianza.

Lipovetsky, G. (2000). El crepúsculo del deber. La ética indolora de los nuevos tiempos democráticos. Barcelona: Anagrama.

Löwy, M. (1990). La escuela de Frankfurt y la modernidad: Benjamin y Habermas. Revista Colombiana de Sociología - Nueva Serie.

Lukács, G. (1985). El alma y las formas. Teoría de la novela. México: Grijalbo.

Maffesoli, M. (1985). De la orgía. Una aproximación sociológica. Barcelona: Ariel.

Magris, C. (1993). El anillo de Clarisse. Tradición y nihilismo en la literatura moderna. Barcelona: Península.

Martínez, F. (1990). Sobre el lirismo. León: Universidad de León.

Platón (1998). Protágoras. Madrid: Alianza. 
Rosero Diago, E. (1992). Señor que no conoce la luna. Bogotá: Planeta.

Sennett, R. (1978). El declive del hombre público. Barcelona: Península.

Touraine, A. (2000). Crítica de la modernidad. México: Fondo de Cultura Económica.

Vattimo, G. (1990). La sociedad transparente. Barcelona: Paidos. 